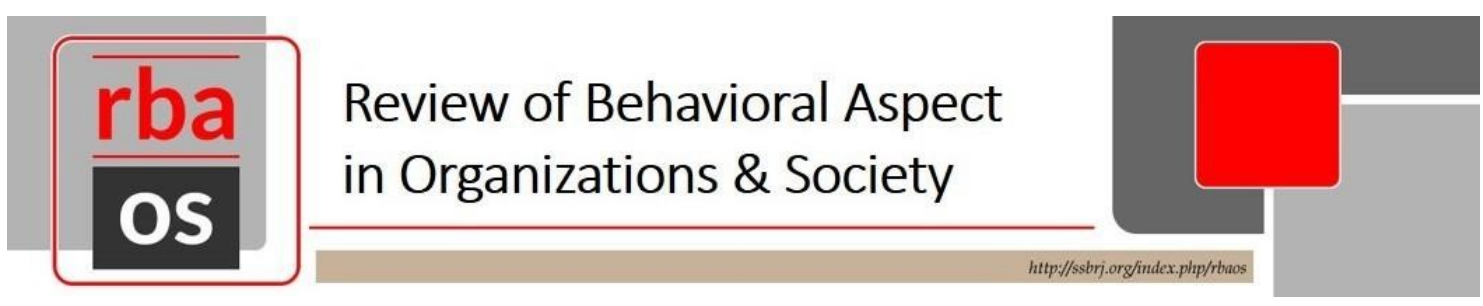

\title{
THE EFFECT OF GOOD CORPORATE GOVERNANCE AND MACROECONOMICS FACTORS TOWARDS FINANCIAL DISTRESS
}

\author{
Lilis Saidah Napisah, STIE EKUITAS, Indonesia
}

\begin{abstract}
The purpose of this research is to determine the effect of Good Corporate Governance and macroeconomics factors on financial distress. This research used a descriptive verification method with a quantitative approach. The type of data that is used is secondary data from company financial reports and publication data needed to support this research. The population in this research is Retail Trade Company registered in the Indonesia Stock Exchange period 2012-2016. Analysis of data used multiple linear regression analysis. The result of this research that used multiple linear regression analysis, concluded as follows: Institutional ownership has a negative effect financial distress with a significant value of $1 \%$, the independent commissioner has a negative effect financial distress with a significant value of $2.1 \%$ with a significant level of $5 \%$. Good corporate governance and macroeconomics factors simultaneously affect to financial distress with a significant value of $2.8 \%$.

Keywords: Good Corporate Governance, macroeconomics factors, financial distress
\end{abstract}




\section{Introduction}

The National Statistics Department was having a data from the third quarter of 2017 that the domestic consumption is only 4,93\%. The number is slowing than in the first quarter of 2017 that has $4,94 \%$. Based on the National Statistics Department data, the decreasing number of domestic consumption is affecting the community buying power. This thing is causing the retail's suddenly closing their shops to anticipate the digital economy in Indonesia. (manado,tribunnews.com). According to Fachrudin (2008), there are a few definition of financial distress; one of them is technical insolvency. A company is entering the technical insolvency if the company cannot fulfill their obligations. If the technical insolvency is happening, it could be called as the first stages of bankruptcy.

There are a few models or techniques that could be used to predict financial distress. One of them is the research that Beaver (Endang, 2012) conducted about "financial ratios as predictors of failure". In that study, Beaver using 5 financial ratios that have an error rate below $24 \%$. But one of the mistakes in that study is the usage of univariate analysis, which cannot make a simultaneous model that could be used to predict a company's failure (Iramani, 2008).

Besides all of the theory above, there some case that related to this case, PT. Nyonya Meneer who's established since 1919, is declared bankrupt by the Semarang State Court. The high debt is making the company no longer in good health. They also have an internal family problem. Didik J. Rachbini, a Senior economic in the Institute for Development of Economics and Finance (INDEF) is explaining how a company could get bankrupt even they're already running for a long time, in this case, PT. Nyonya Meneer. They are one of the corporations that can't deal with a rapid change. He said if the company is forcing to keep operating in bad condition, they will have a big debt coming for them (merdeka.com).

Next, there is a case from PT. Modern International, Industrial Minister Airlangga Hartanto, evaluating that the reason why all the 7-Eleven closed is that there's a problem in their internal management, not because of the retail business climate. He's explaining that 7Eleven is a company that has a few stakeholders. They are having more dynamics because every stakeholder is having a different approach on how they do business. One of the closed 7-Eleven stores in Jakarta is in the Indonesia Stock Exchange building. Tina Novita, Corporate Secretary of PT. Modern Putra Indonesia said that a few stores that closed early this year are because they can't achieve the company goals. Tina said that since 2015, 7Eleven income is kept decreasing because the economic situation is getting weaker, the minimarket sector is getting more competitive, and the customers buying power is getting weaker (finance.detik.com).

Based on the phenomena above, we can see that how the corporate handle their problem and the economic factors is becoming the primary concern in how a company controls themselves. The attention at governance practices in modern companies is increasing. Especially since the collapse of the big companies in the world. So, the writer is choosing the title of this study "The Effect of Good Corporate Governance and Macroeconomics Factors Towards Financial Distress (A Case Study on Retail Trading Company listed on BEI period 2012-2016)"

\section{Literature Review Good Corporate Governance}


The terms of Corporate Governance introduced firstly by Cadbury Committee in 1992 in their report called The Cadbury Report. Agoes (2014:101). According to Josep in Fahmi (2014), Corporate Governance is a few people who united by some tasks and responsibilities to direct, control, and play a role in their authorizations. In a company, this council is ade to organize, decide, control, and do the city's authority that given to them.

\section{The Meaning of Macroeconomics}

The macroeconomics is an analysis in economic science that pictures everything about economic activity. The report is not only some consumer activities or the producers but all of the consumers and producers in that economy activities (Sukirno, 2013). Macroeconomy Science is a study about the symptoms or the economic phenomena broadly. The macroeconomy science is talking about production in a whole process, not only per company like the micro economy did. In discussing the economy as a whole, the macroeconomy focuses all the attention on the economic policy and any other variables that have an impact on it. For example, the macroeconomy talks about unemployment nationally, national income, and national inflation rate (Sukwiaty et.al., 2009).

\section{Financial distress}

According to Plat and Plat (2002) on Fanny (2017), Financial Distress is a drop in financial condition that happened before the bankruptcy happened or a liquidation. The financial distress condition could be seen from the net income amount of a company that has a negative value. According to Brigham and Daves in Hidayat (2014), the financial difficulties could've happened by a few mistakes, the decision making that's not precise, and a few weaknesses that connected to each other to the management; also the lack of supervising on the company financial condition can lead to financial distress.

\section{The Influence of Good Corporate Governance towards Financial distress \\ a. $\quad$ The influence of institutional ownership towards financial distress}

The institutional ownership is a percentage of stock ownership owned by the legal entity or some financial institution like an insurance company, pension funds, mutual funds, bank, and any other institutions (Brigham and Houston on Ayuningtyas, 2013). With the institutional ownership exist, the investors will get more trust in the companies and will become an added value to the companies.

The result from Wardhani's (2007) research says that the structure of ownership represented by the financial institutional ownership and board of owners resulting in some insignificant values. The study discusses that the commitment from the owners will not affect the company's financial condition. The company's financial condition is more affected by the decisions that took by the director and commissioners. That situation shows that the more significant the proportion of institutional ownership, the bigger the supervision that should be done to the company managers, so the company potential to have financial difficulties is likely smaller.

\section{b. The Influence of independent commissionaire towards Financial distress}

According to OJK regulations No. 33/POJK/2014, the independent commissionaire is a member of the board of commissionaires that come from outside of the company who's in charge of supervising in general and giving advice to the director. The agency theory says that the independent commissionaire is needed in the board of commissionaires to supervising and control what the directors decide, based on their opportunistic behavior (Jensen and Meckling, in Ariesta 2013). Wardhani on Sastriana (2013) says that the greater 
the number of independent commissionaires member in a company, the smaller the chance of that company will have financial distress. The function of independent commissionaire is supervising the director performance at monitoring financial problem, so he will not make a decision that could make the company having a loss, the higher the proportion of independent commissionaire on supervising the director, the lower the chance of the company will have a financial distress.

\section{c. $\quad$ The Influence of the board of directors towards Financial distress}

According to Sastriana and Fuad (2013) the board of directors having an essential part in corporate governance because the higher number of board of directors number could help the company on taking policies that useful for the company. The research by Manzaneque (2015) presents that the board of director have a negative influence on financial distress. The result finds that more members in the board of directors could give more trust to the director so it can improve the access for information and improving the director's sense of controlling the company management.

\section{d. The influence of audit committee towards Financial distress}

The audit committee is built by the board of company commissionaire to help check or do some research that needed for the director managing the company. Samsul (2007:72). Based on the rules of OJK No. 55, the audit committee is at least consisting of 3 members that came from independent commissionaire. With the audit committee that consists more from 1 person, the company is expecting to conduct a meeting and share their thoughts. The research that conducted by Ariesta (2013) explaining that the independencies of the audit committee are having a negative impact on financial distress. This means that it could help the company avoiding financial distress.

\section{The effect of Macroeconomics Factors towards Financial distress \\ a. $\quad$ The effect of inflation rate towards Financial distress}

Inflation is the increase in prices that applied in some economies from one period to another. According to Munthe on Darmawan (2016) the increase on the price of the products will make the capital costs, employee costs, and raw material costs increasing unexpectedly. If that increase in costs is not offset by an increase in the product selling price to the consumers, the company will expect a loss. The research by Nittayageswat in Endang (2012) showing that inflation is the thing of predicting bankruptcy. So, if there's an increase in production costs, the price of the product should be increased too. If the decline in income occurs continuously then the possibility of financial distress will likely be higher.

\section{b. $\quad$ The effect of interest rate towards Financial distress}

The interest rate can be interpreted as a rate that is given to the borrower or the price of the loan itself. The higher interest rate surely will incriminate a company that will make a new investment, especially a company that has a high loan ratio; this will make the company's performance going downhill. According to Bingham in Darmawan (2016), he says that the bigger the interest that the company bear, the probability of the company's revenue going downhill will be more significant too, all of that will lead the company to have financial distress.

\section{c. $\quad$ The effect of exchange rate towards Financial distress}

Sukirno (2013) explains that the exchange rate is a denomination that shows the amount of the domestic currency that needed to get one unit of foreign currency. The rupiah's exchange rate is very influencing the company that has their raw material through import. The rupiah's 
depreciation will make the production costs getting higher, so it'll make the company's profitability go down (Darmawan 2016). This will make the company's having financial distress.

These are the study paradigm that taken from the study framework above:

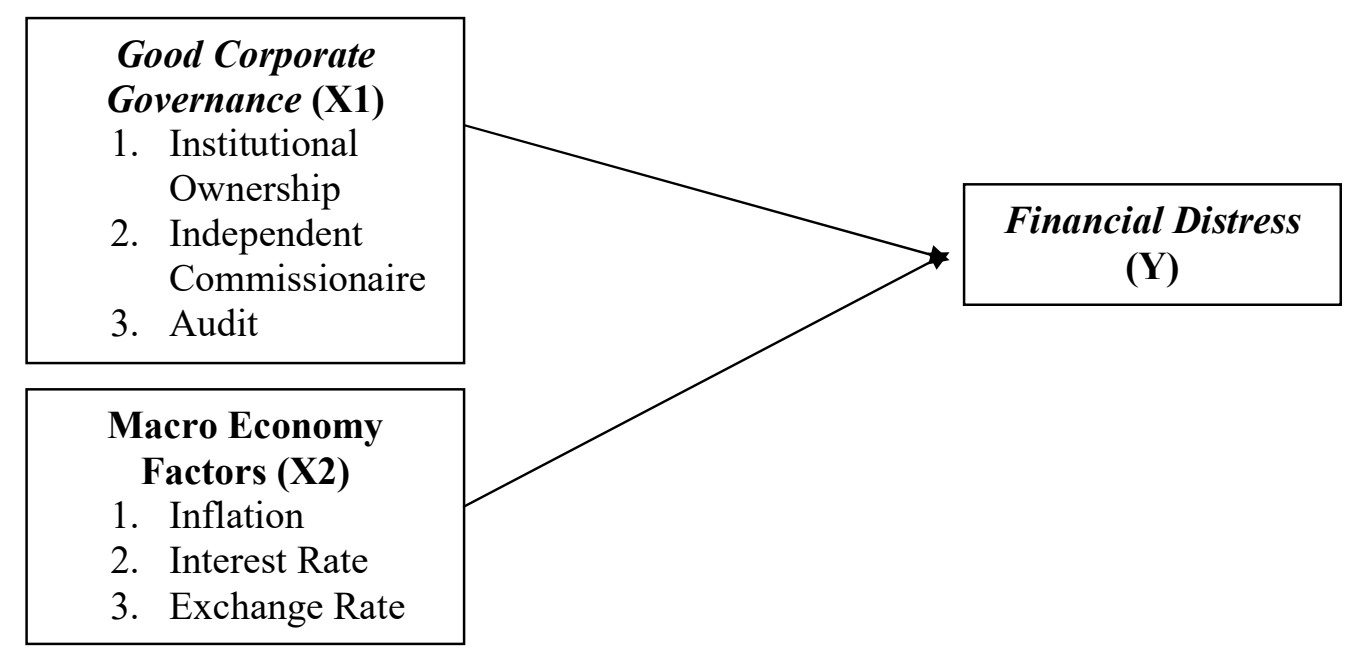

Figure 1. Research Paradigm

\section{Discussion}

Good Corporate Governance application into a retail trading company that enlisted in BEI on 2012-2016 period

The good corporate governance which contained on the retail trading company that enlisted in BEI on 2012-2016 period is institutional ownership, independent commissionaire proportion, the numbers of board of director, and the numbers of the audit committee. And the macroeconomy factors which consisting of the inflation rate, interest rate, and exchange rate.

The institution stock ownership on a retail company that enlisted in BEI on 2012-2016 period In 2012-2016, the highest institutional stock ownership is found on the Kokoh Inti Arebama Tbk. This data indicates that the institutional investor is having more trust in that company so the company performance is doing well. Meanwhile, the lowest institutional stock ownership in 2012-2013 is found at Catur Sentosa Adiprana Tbk. On 2015 to 2016 found at Matahari Department Store Tbk. This shows that the ownership of Matahari Department Store Tbk. Stock is mainly owned by the public.

Independent commissionaire proportion on the retail companies that listed in BEI on 20122016 period

The highest percentage of independent commissioners was in 2012-2014 owned by Midi Utama Indonesia and in 2015 it was found in Ramayana Lestari Sentosa Tbk, Midi Utama Indonesia Tbk, Ace Hardware Indonesia Tbk. In 2016 there were Midi Utama Indonesia Tbk, Centratama Telekomunikasi Indonesia Tbk, Sumber Alfaria Trijaya Tbk, and Ace Hardware Indonesia Tbk. It shows that the company has complied with the regulations set by OJK that the company is at least have $30 \%$ of the board of commissioners so that supervision 
performance of directors will be better. The lowest proportion of independent commissioners in 2015 is at Centratama Telekomunikasi Indonesia Tbk. It shows that the company cannot fulfill the regulations set by the OJK so that supervision of the performance of directors is less than optimal.

The number of boards of directors in retail trading companies registered on the IDX for the period 2012-2016

In the period 2012-2014, the highest number of board of directors is found in Sumber Alfaria Trijaya Tbk, while on the period 2015-2016 there are companies from Sumber Alfaria Trijaya Tbk, Mitra Adi Perkasa Tbk, and Sona Topas Tourism Tbk and Supra Boga Lestari Tbk. This shows that the company has complied with the regulations set by the OJK, namely having a board of directors of more than 2 people. The lowest number of board of directors is in 20122014, namely in the company Golden Retailindo Tbk, while in 2015-2016 there is the company Centratama Telekomunikasi Indonesia Tbk, Golden Retailindo Tbk, Kokoh Inti Arebama Tbk. It shows that even though the company has complied with the OJK stipulated regulations, the amount is considered too low, where the OJK determines the number of directors of the public companies at most consists of 2 people.

The number of audit committees in retail trading companies registered on the IDX in the period 2012-2016

The highest number of audit committees was in 2012 and 2013 in the Matahari Department Store Tbk. While the lowest number of audit committees was in 2014, namely as many as 2 people in the company Golden Retailindo Tbk. This shows that the company cannot fulfill the regulations issued by the OJK, namely the audit committee consists of at least 3 people.

\section{Macroeconomics Conditions in Indonesia for the 2012-2016 period}

a. Inflation rate in Indonesia for the 2012-2016 period

The inflation rate in Indonesia for the 2012-2016 period has fluctuated from time to time. The highest inflation rate in 2013 was $8.38 \%$. Based on information from the BPS this happened because of the increase in prices of food commodities as well as the increase in fuel prices which was accompanied by an increase in the price of public transport fares. In 2016 the inflation rate was at the level of 3.02\%, which made inflation the lowest in the 2012-2016 period. This shows that economic conditions in Indonesia in 2012 were relatively stable.

\section{b. $\quad$ Interest rates in Indonesia for the 2012-2016 period}

Bank Indonesia interest rates for the 2012-2016 period have fluctuated from time to time. The highest interest rate in 2014 was 7.54\%. This was due to the increase in the inflation rate in 2013 and 2014, because the government raised the price of fuel, so that BI set a higher interest rate in the last two years, namely in 2014 and 2015 as a strategy to reduce the inflation rate. In 2016 the interest rate was at the level of 5.58\%, which made it the lowest inflation. This is because the economic conditions in Indonesia are relatively stable.

c. $\quad$ The Rupiah exchange rate in Indonesia for the 2012-2016 period

The development of the exchange rate (USD / IDR) for the 2012-2016 period tends to weaken or depreciate from year to year. The highest exchange rate is in 2016, which is Rp. 13.308.-. Based on information from Bank Indonesia, the depreciation of the rupiah was caused by the Fed's plan or the benchmark interest rate of the American central bank that would rise, causing pressure on the rupiah itself. While the lowest exchange rate was in 2012, which was Rp. 9670, -. This condition shows that the rupiah exchange rate against USD is in a stable position. 
The condition of the financial distress of retail trading companies listed on the IDX for the period 2012-2018

The companies that experiencing 3 conditions of financial distress or financial difficulties, namely the company Sumber Alfaria Tbk, Chess Sentosa Adiprana Tbk, Midi Utama Indonesia Tbk. It is because the company experienced a decline in profits during the period 2012-2016 and the company has a negative working capital, which indicates that the current assets of the company are not sufficient to meet its current liabilities. While retail trading companies that are in a healthy condition or not likely to experience 9 financial distress companies, namely Ace Hardware Indonesia Tbk, Centratama Telekomunikasi Indonesia Tbk, Golden Retailindo Tbk, Kokoh Inti Arebama Tbk, Matahari Department Store Tbk, Matahari Putra Prima Tbk, Ramayana Lestari Sentosa Tbk, Sona Topas Tourism Industry Tbk, and Supra Boga Lestari Tbk. And one company that is in the gray area, namely Mitra Adi Perkasa Tbk.

\section{The Effect of Good Corporate Governance towards Financial Distress}

In this study, good corporate governance indicators used are institutional ownership, independent commissioners, the board of directors, and audit committees.

\section{a. The Effect of institutional ownership towards financial distress}

Based on the results of all the tests that have been done, it can be concluded that institutional ownership has a negative effect on financial distress with a significance level of 0.010 . It shows that the greater the percentage of institutional share ownership (INST) can reduce the possibility of companies experiencing financial distress. Institutions play an active role in the supervision of companies, so management will be more careful in making decisions, and the option of companies experiencing financial distress conditions will be even smaller.

With the existence of institutional ownership, investors tend to be more trusting the company, and this could become an added value for the company. Wardhani in Sastriana and Fuad (2013) states that the greater the proportion of institutional ownership, the higher the supervision carried out on company managers so that the potential of companies to experience financial difficulties will be smaller. The results of this study are also in line with the research conducted by Emrinaldi in Laurenzia and Sufiyati (2015), Deviacita and Achmad (2012), stating that institutional ownership has a negative effect on financial distress.

\section{b. $\quad$ The influence of an independent commissioner towards Financial distress}

Based on the results of all the tests that have been done, it can be concluded that the number of independent commissioners harms financial distress with a significance level of 0.021 . It shows that the higher the proportion of independent commissioners, the better the supervision of the performance of directors will affect the lower the company's financial difficulties. The function of independent commissioners in monitoring the performance of directors in terms of monitoring financial issues is to prevent directors from harming the company.

Agency theory assesses that independent commissioners are needed on the board of commissioners to oversee and control the actions of directors in connection with their opportunistic behavior Jensen and Meckling in Ariesta (2013). The higher the proportion of independent commissioners, the more increasing the monitoring or evaluation of company performance so that the possibility of financial difficulties for companies will be lower (Deviacita and Achmad 2012). This research is in line with the study conducted by Huang 
and Zhao in Deviacita (2012), Emrinaldi in Wayan and Lely (2014), stating that independent commissioners have a negative effect on financial distress.

\section{c. $\quad$ Effect of the Board of Directors towards financial distress}

Based on the results of all the tests that have been done, it can be concluded that the number of directors does not partially influence financial distress with a significance level of 0.171 . This shows that the size of the board of directors owned by the company has no influence on the condition of the company's financial difficulties because the division of duties and authority of members of the board of directors is determined through the GMS as stipulated in limited liability company regulations. But a fixed decision is taken at the General Meeting of Shareholders (GMS). The board of directors in a company will determine the policies or strategies that will be taken for the company, both short and long term. These strategies and policies can be used to prevent companies from being in financial difficulties.

The good corporate governance mechanism is only used as a formality so that it is unable to predict a company experiencing financial distress. In this case, the corporate good corporate governance mechanism needs to be improved so that it is not considered a formality (Fidyaningrum, 2017). This research is in line with the research conducted by Cinantya and Merkusiwati (2015), Durri (2017), Ellen and Juniarti (2013) that the board of directors does not affect financial distress.

\section{d. $\quad$ The influence of the audit committee towards financial distress}

Based on the results of all the tests that have been done, it can be concluded that the number of audit committees partially does not affect financial distress with a significance level of 0.569 . This shows that whatever the number of audit committees does not make the company in a state of financial difficulties because the competencies possessed by the audit committee are able to monitor operational conditions and make corrections to the company's financial condition early so it is useful for management to find out whether the company will experience financial difficulties or not.

The audit committee is a mechanism of good corporate governance. A competent audit committee can change policies that are different in achieving accounting profits in the next few years. The size of the audit committee is able to support the effectiveness of the performance of the audit committee of a company. A larger audit committee has the ability to find and resolve problems in the financial reporting process and is able to improve the quality of discussions between members of the Nuresa audit committee (2013). This research is in line with the study conducted by Putri (2014) and Kusanti (2015) that audit committees do not affect financial distress.

\section{The effect of macroeconomics factors towards financial distress}

In this study, the macroeconomics factors used are inflation rates, interest rates, and exchange rates.

\section{a. The effect of the inflation rate on Financial Distress}

Based on the results of all the tests that have been done it can be concluded that the inflation rate does not affect financial distress with a significance level of 0.581 . Inflation in Indonesia during the observation period of 2012-2016 experienced a relatively stable development. Inflation will affect the price of goods and will affect the ability of consumers to buy goods and then will affect income. It shows that there is no significant change in inflation, so it will not affect the possibility of financial distress. 
Inflation itself is an increase in general prices that are valid for another period. According to Munthe in Darmawan (2016) the increase in product prices will cause an unexpected increase in production costs. If the increase in costs is not offsetted by an increase in the selling price of products to consumers, then the company will suffer losses. This research is in line with the research conducted by Darmawan (2017), Allisa (2013) that the inflation rate does not affect financial distress.

\section{b. $\quad$ The effect of interest rate to financial distress}

Based on the results of the tests that have been done it can be concluded that interest rates do not affect financial distress with a significance level of 0.510 . Interest rates will change debt as a result of loans with interest charges which will ultimately reduce profits. The interest rate that occurred in Indonesia during the study period, namely 2012-2016, there was no significant change in interest rates, so that it would not have much effect on financial distress.

According to Brigham in Darmawan (2016) said that the higher the interest expense that is borne by the company, the higher the probability of a decrease in income will be higher so that it will lead to financial difficulties. The results of this study are in line with the research conducted by Darmawan (2017), Desiyani (2011), which states that interest rates do not affect financial distress.

\section{c. $\quad$ The Exchange Rate Influence on Financial Distress}

Based on the results of all the tests that have been done, it can be concluded that the exchange rate does not affect financial distress with a significance level of 0.183 . The exchange rate will affect only companies that use debt in foreign currencies and companies that use imported raw materials because the depreciation of the rupiah will cause an increase in production costs so that it will reduce profitability and make the company in a state of financial distress. The results of the study are not too many companies that use loans in the form of foreign currencies and use imported raw materials. The development of the rupiah exchange rate in Indonesia during the study period, 2012-2016, did not experience significant changes so that it did not affect financial distress. This research is in line with the research conducted by Djumahir (2007) in Darmawan (2017), that the exchange rate does not affect financial distress.

Effect of Good Corporate Governance and Macroeconomics Factors on Financial Distress simultaneously

The results of the tests on this research that has been carried out, namely regarding the independent variables Good corporate governance and macroeconomics factors have an effect on simultaneous financial distress. In general, companies will be more productive if the company is in a stable condition, both in terms of finance, governance, or economic conditions of the country where the company is located. The reason why companies succeed or fail is more due to the strategies implemented by the company. These strategies include strategies for implementing Good corporate governance. Because the strategy applied by managerial is not right, so the company cannot prevent the occurrence of financial difficulties; besides that, if the economic condition in a country is experiencing instability, it will further improve the condition of financial difficulties. This shows that the company does not have the ability to deal with financial risks caused by factors in a country's economic instability. 
The results of the partial $t$ test (t-test) show that $\mathrm{R}$ Square is 0.232 or $23.2 \%$, which means that the percentage contribution to the effect of the independent variable Good corporate governance and macroeconomics factors is $23.2 \%$, while the rest is $76.68 \%$ is influenced by other factors that can affect financial distress that is not examined such as financial ratios and company size. The results of this study are in line with the research conducted by Septriani (2013), which states that good corporate governance and macroeconomics factors have a simultaneous effect on financial distress.

\section{Conclusion}

Based on all of the analysis above, there are a few conclusions from this research:

a. The Good Corporate Governance that applied by the retail trading companies has been appropriate with OJK rules and with Indonesia's macroeconomics condition on a different research period and in a stable condition.

b. The institutional ownership, Independent commissionaire have a negative impact against financial distress. This research is supported by a few past researchers like Emrinaldi in Laurenzia and Sufiyati (2015), Deviacita (2012), Huang and Zhao in Deviacita (2012), Wayan and Lely (2014).

c. Inflation, currency, and the exchange rate doesn't affect financial distress. These findings are supported by the previous researcher (Darmawan, 2017; Allisa, 2013).

d. Good corporate governance and the factors of the macroeconomy is affecting the financial distress simultaneously. This research is supported by the previous researcher, Septriani (2013).

\section{References}

Agoes, S. (2009). Business ethics and professional challenges of building a whole person (in Indonesia: Etika Bisnis dan Profesi Tantangan Membangun Manusia Seutuhnya). Revised Edition. Jakarta: Salemba Empat.

Allisa. (2013). Analysis of the effect of financial ratios and sensitivity of macroeconomics variables on financial distress in manufacturing companies (in Indonesia: Analisis pengaruh rasio keuangan dan sensitivitas variabel ekonomi makro terhadap financial distress pada perusahaan manufaktur). Undergraduate thesis, Perbanas School of Economics.

Ariesta, C. (2013). Analysis of the effect of the structure of the board of commissioners, the structure of share ownership and audit committee on financial distress (in Indonesia: Analisis pengaruh struktur dewan komisaris,struktur kepemilikan saham dan komite auditterhadapfinancial distress). Diponegoro Journal of Accounting, 1(1), 1-9.

Ayuningtyas. (2013). Analysis of the effect of ownership structure, board composition, and agency cost on financial distress (in Indonesia: Pengaruh struktur kepemilikan, board composition, dan agency cost terhadap financial distress). Journal of Management Science, 1(1), 1-14.

Cinantya, \& Merkusiwati. (2015). The effect of corporate governance, financial indicators, and company size on financial distress (in Indonesia: Pengaruh corporate governance, financial indicators, dan ukuran perusahaan pada financial distress), E-Jurnal Akuntansi,10(3), 897-915.

Darmawan. (2017). Analysis of the influence of corporate governance, macroeconomics variables on financial distress with control variables of firm size and type of ownership (in Indonesia: Analisis pengaruh corporate governance, variabel ekonomi makro terhadap financial distress dengan variabel kontrol ukuran perusahaan dan jenis kepemilikan). Efektif Jurnal Ekonomi dan Bisnis, 7(1), 100-122. 
Desiyani, N. (2011). Analysis of the effects of macro and micro indicators on bankruptcy predictions (in Indonesia: Analisis pengaruh indikator makro dan mikro terhadap prediksi kebangkrutan studi kasus pada perusahaan manufaktur yang terdaftar di bursa efek Indonesia tahun 2007-2009). Thesis. Universitas Sebelas Maret.

Deviacita, A.W. (2012). Analysis of the effect of corporate governance mechanisms on financial distress (in Indonesia: Analisis pengaruh mekanisme corporate governance terhadap financial distress). Doctoral dissertation. Faculty of Economics and Business, Diponegoro University.

Durri, Z.S. (2017). Analysis of the effect of financial ratios and corporate governance mechanisms on financial distress (in Indonesia: Analisis pengaruh rasio keuangan dan mekanisme corporate governance terhadap financial distress). Thesis. Muhammadiyah University Surakarta.

Ellen \& Jurniarti. (2013). Implementation of GCG, its impact on prediction o financial distress in miscenallenous and consumption industry (in Indonesia: Penerapan GCG, dampaknya terhadap prediksi financial distress pada sektor aneka industri dan barang konsumsi). Business Accounting Review, 1(2), 1-13.

Fachrudin, K A. (2008). Corporate and personal financial difficulties (in Indonesia: Kesulitan keuangan perusahaan dan personal). Medan: USUpress.

Fahmi, I. (2011). Financial statement analysis (in Indonesia: Analisis Laporan Keuangan). Bandung: Alfabeta.

Fanny, A.T. (2017). Comparative analysis of financial distress prediction models in plantation sub sector (in Indonesia: Analisis perbandingan model prediksi financial distress pada sub sektor perkebunan). Jurnal Ilmu \& Riset Akuntansi, 6, 1-15.

Hidayat, M. (2014). Financial distress prediction of manufacturing companies in Indonesia (in Indonesia: Prediksi financial distress perusahaan manufaktur di Indonesia). Doctoral dissertation. Diponegoro University.

Kusanti, O. (2015). The effect of Good Corporate Governance and financial ratios on financial distress (in Indonesia: Pengaruh Good Corporate Governance dan rasio keuangan terhadap financial distress). Jurnal Ilmu \& Riset Akuntansi, 4(10), 1-22.

Laurenzia \& Sufiyati. (2015). Effect of institutional ownership, board of commissioners size, liquidity, activities and leverage on financial distress of manufacturing companies listed on the Indonesia Stock Exchange (IDX) period 2013-2014 (in Indonesia: Pengaruh kepemilikan institusional, ukuran dewan komisaris, likuiditas, aktivitas dan leverage terhadap financial distress perusahaan manufaktur yang terdaftar di Bursa Efek Indonesia (BEI) periode 2013-2014). Journal of Economics, 10(1), 72-88.

Manzaneque, M., Priego, A. M. \& Merino, E. (2016). Corporate governance effect on financial distress likelihood: Evidence from Spain. Revista de Contabilidad, 19(1), 111121.

Nuresa. (2013). Effect of audit committee effectiveness on financial distress (in Indonesia: Pengaruh efektivitas komite audit terhadap financial distress). Diponegoro Journal of Accounting, 2(2), 1-10.

Putri, N. W. K. A., \& Merkusiwati, N. K. L. A. (2014). Effects of corporate governance, liquidity, leverage, and firm size mechanisms on financial distress (in Indonesia: pengaruh mekanisme corporate governance, likuiditas, leverage, dan ukuran perusahaan pada financial distress). Journal of Accounting at Udayana University, 7(1), 93-106.

Samsul, M. (2006). Capital market and portfolio management (in Indonesia: Pasar Modal dan Manajemen Portofolio). Jakarta: Erlangga.

Sastriana \& Fuad. (2013). The effect of corporate governance and firm size on companies experiencing financial distress (in indonesia: pengaruh corporate governance dan firm 
size terhadap perusahaan yang mengalami kesulitan keuangan (financial distress). Diponegoro Journal of Accounting, 2(3), 1-10.

Sukirno, S. (2013). Microeconomics introduction theory (in Indonesia: Mikroekonomi teori pengantar). Third Edition. Jakarta: Raja Grafindo Persada.

Wardhani, R. (2006). Corporate governance mechanisms in companies that have financial problems (in Indonesia: Mekanisme corporate governance dalam perusahaan yang mengalami permasalahan keuangan). National Symposium on Accounting 9, 1-26.

Wayan \& Lely. (2014). The effect of corporate governance, liquidity, leverage and firm size mechanisms on financial distress (in Indonesia: Pengaruh mekanisme corporate governance, likuiditas, leverage dan ukuran perusahaan pada financial distress). EJournal of Accounting, 1, 93-106. 